\title{
Efikasi Terapi Kombinasi \\ Salep Kalsipotriol 0,005\% dan Klobetasol Propionat 0,05\% Dibanding Klobetasol Propionat 0,05\% pada Psoriasis Vulgaris
}

\author{
Dian Indriyani, Endang Sutedja, Oki Suwarsa \\ Bagian Ilmu Kesehatan Kulit dan Kelamin \\ Fakultas Kedokteran Universitas Padjadjaran \\ Rumah Sakit Hasan Sadikin, Bandung
}

\begin{abstract}
Abstrak
Psoriasis adalah penyakit eritropapuloskuamosa kronik residif. Obat yang paling sering digunakan untuk terapi penyakit ini adalah kortikosteroid topikal, tetapi penggunaan jangka panjang dapat menyebabkan berbagai efek samping. Kalsipotriol merupakan obat topikal selain kortikosteroid yang memiliki efek samping yang lebih ringan. Tujuan penelitian ini adalah untuk membandingkan skor psoriasis area and severity index (PASI) sebelum dan sesudah pengobatan dengan kombinasi salep kalsipotriol 0,005\% dengan salep klobetasol propionat $0,05 \%$ dan monoterapi salep klobetasol propionat $0,05 \%$ pada penderita psoriasis vulgaris. Skor psoriasis area severity index (PASI), digunakan untuk mengukur berat ringannya psoriasis dan mengevaluasi perbaikan lesi. Desain penelitian adalah uji klinik dengan rancangan acak secara double blind. Uji Mann-Whitney dan Wilcoxon digunakan untuk menganalisis data skor PASI sebelum dan sesudah pengobatan. Penelitian dilakukan di poliklinik I.K. Kulit dan Kelamin RS. Hasan Sadikin Bandung dari bulan November 2007- Januari 2008 dengan subjek penelitian sebanyak 44 orang yang dibagi dalam dua kelompok. Derajat keparahan penyakit dinilai dengan skor PASI yang dinilai sebelum, satu minggu, dan dua minggu setelah pengobatan. Kesimpulan: Penggunaan terapi kombinasi salep kalsipotriol $0,005 \%$ dan klobetasol propionat $0,05 \%$ selama dua minggu memiliki efikasi yang lebih baik dibandingkan monoterapi salep klobetasol propionat $0,05 \%$, secara statistik sangat bermakna $(\mathrm{p}<0,001)$.
\end{abstract}

[MKB. 2010;42(1):17-21].

Kata kunci: Salep kalsipotriol 0,005\%, salep klobetasol propionat 0,05\%, psoriasis vulgaris

\section{Efficacy Combination Therapy of $0.005 \%$ Calcipotriol and $0.05 \%$ Clobetasol Propionat Compared to $0.05 \%$ Clobetasol Propionat Ointment in Psoriasis Vulgaris}

\begin{abstract}
Psoriasis is a chronic relapsing erythropapulosquamous skin disease. Topical corticosteroid is the most common treatment for psoriasis, but it can cause many side effect on longterm used. Calcipotriol ointment is the other topical treatment for psoriasis and has minimal side effect. The study was a double blind randomized clinical trial, compared psoriasis area and severity index score before and after treatment combination therapy of $0.005 \%$ calcipotriol ointment $0.05 \%$ and clobetasol propionat ointment with $0.05 \%$ clobetasol propionat alone. Psoriasis area severity index (PASI) score was used to evaluate severity degree and imprvoment of psoriasis. Mann-Whitney and Wilcoxon test were used for statistical analysis of PASI score before and after treatment. Study was conducted at Dermatology and Venereology outpatient Department of Hasan Sadikin Hospital Bandung period November 2007 to January 2008 with fourty four psoriasis vulgaris patients were enrolled in this study, divided into two groups. The assesment of the severity of skin lesions psoriasis area and severity index was performed at baseline, after one week and two weeks treatment. Conclusion: the use of daily $0.005 \%$ calcipotriol ointment combined with $0.05 \%$ clobetasol propionate
\end{abstract}

Korespondensi: dr. Dian Indriyani, Bagian Ilmu Kesehatan Kulit dan Kelamin, Fakultas Kedokteran Universitas Padjadjaran, Rumah Sakit Hasan Sadikin, Jln. Pasteur 38 Bandung, Hp. 08157166995 
ointment after two weeks has better efficacy than $0.05 \%$ clobetasol propionate ointment alone in the treatment of psoriasis vulgaris and statistically highly significant $(p<0.001)$. [MKB. 2010;42(1):17-21].

Key words: $0.005 \%$ calcipotriol ointment, $0.05 \%$ clobetasol propionate ointment, psoriasis vulgaris

\section{Pendahuluan}

Di Indonesia obat yang paling sering digunakan untuk terapi psoriasis secara topikal adalah tar dan kortikosteroid, tetapi pemakaian kortikosteroid dan tar ini memiliki keterbatasan. ${ }^{1}$ Tar sudah sejak lama digunakan pada pengobatan psoriasis, tetapi sedikit yang diketahui cara kerja tar pada kulit. ${ }^{2}$ Efek samping kortikosteroid menyebabkan penggunaannya terbatas, maka penggunaan terapi kombinasi salep kalsipotriol dan kortikosteroid superpoten ini diharapkan dapat meningkatkan efikasi dan meringankan efek samping. ${ }^{3}$

\section{Metode}

Kriteria inklusi adalah semua penderita psoriasis vulgaris berusia $\geq 18$ tahun, sedangkan kriteria eksklusi adalah yang mendapat pengobatan psoriasis sistemik dalam empat minggu terakhir dan pengobatan psoriasis topikal dalam dua minggu terakhir, wanita hamil, lesi luas yang memerlukan pengobatan topikal lebih dari 50 gram/minggu, menderita stroke, asma, hipertensi dan infark miokardium akut. Penelitian dilakukan di poliklinik Ilmu Kesehatan Kulit dan Kelamin RS. Hasan Sadikin Bandung dari bulan November 2007-Januari 2008. Penelitian ini merupakan suatu uji klinik fase III dengan rancangan acak (randomized clinical trial) dan pengamatan berulang (pre-post) secara double blind dengan menggunakan skor psoriasis area and severity index (PASI). Alokasi subjek penelitian pada masing-masing kelompok dilakukan secara blok permutasi acak (random permuted block). Kemaknaan ditentukan berdasarkan nilai $p<0,05$.

\section{Hasil}

Tabel 1 menunjukkan bahwa pada kelompok I didapatkan hasil skor PASI rata-rata sebelum pengobatan adalah 12,3; simpangan baku 5,70; median 10,8; dan rentang 3,6-25. Setelah pengobatan satu minggu tampak skor PASI ratarata turun menjadi 4,66 (penurunan 61,6\%) simpangan baku 3,56; median 3,6 dan rentang antara 0,4-15. Secara statistik penurunan ini sangat bermakna $(\mathrm{Zw}=4,107 ; \mathrm{p}<0,001)$. Setelah dua minggu pengobatan, skor PASI rata-rata turun menjadi 0,37 (penurunan 97,7\%) dengan simpangan baku 0,66 ; median 0 dan rentang antara 0-2,4. Penurunan skor PASI setelah pengobatan selama dua minggu pada kelompok I, bila dibandingkan setelah pengobatan satu minggu maupun sebelum pengobatan secara statistik sangat bermakna $(\mathrm{Zw}=4,107 ; \mathrm{p}<0,001$; $\mathrm{Zw}=4,107 ; \mathrm{p}<0,001)$.

Pada kelompok II didapatkan skor PASI rata-

Tabel 1 Skor Psoriasis Area Severity Index (PASI) Rata-rata pada Kelompok I dan II

\begin{tabular}{|c|c|c|c|c|}
\hline \multirow{2}{*}{ Skor PASI } & \multicolumn{2}{|c|}{ Kelompok } & \multirow[t]{2}{*}{ Nilai $Z_{M-W}$} & \multirow[t]{2}{*}{ Nilai $p$} \\
\hline & $I(n=22)$ & II $(n=22)$ & & \\
\hline \multicolumn{5}{|l|}{ Awal } \\
\hline $\mathrm{X}(\mathrm{SB})$ & $12,23(5,70)$ & $10,35(4,15)$ & 0,364 & 0,716 \\
\hline Median & 10,8 & 9,5 & & \\
\hline Rentang & $3,6-25$ & $4,2-21,2$ & & \\
\hline \multicolumn{5}{|l|}{ Satu minggu pengobatan } \\
\hline $\mathrm{X}(\mathrm{SB})$ & $4,66(3,56)$ & $4,99(2,91)$ & 0,623 & 0,534 \\
\hline Median & 3,6 & 4,5 & & \\
\hline Rentang & $0,4-15$ & $0,6-13,2$ & & \\
\hline \multicolumn{5}{|l|}{ Dua minggu pengobatan } \\
\hline $\mathrm{X}(\mathrm{SB})$ & $0,37(0,66)$ & $1,53(1,60)$ & 3,245 & 0,001 \\
\hline Median & 0 & 1,2 & & \\
\hline Rentang & $-2,4$ & $0-6,6$ & & \\
\hline & $x^{2} F=44,0$ & $x^{2} F=44,0$ & & \\
\hline & $\mathrm{p}<0,001$ & $\mathrm{p}<0,001$ & & \\
\hline
\end{tabular}


Tabel 2 Perbandingan Persentase Penurunan Skor PASI

\begin{tabular}{|c|c|c|c|c|}
\hline \multirow{2}{*}{$\begin{array}{c}\text { Persentase Penurunan } \\
\text { Skor PASI }\end{array}$} & \multicolumn{2}{|c|}{ Kelompok } & \multirow{2}{*}{ Nilai $Z_{M-W}$} & \multirow{2}{*}{ Nilai $p$} \\
\hline & I (\%) & II (\%) & & \\
\hline Satu minggu pengobatan & 61,6 & 51,3 & 1,949 & 0,051 \\
\hline Dua minggu pengobatan & 97,7 & 89,1 & 3,651 & $<0,001$ \\
\hline
\end{tabular}

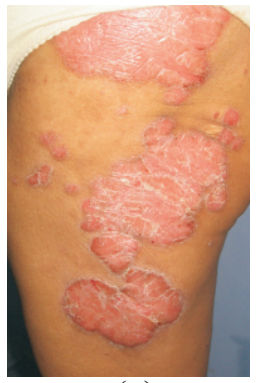

(a)

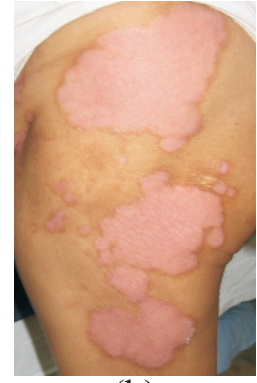

(b)

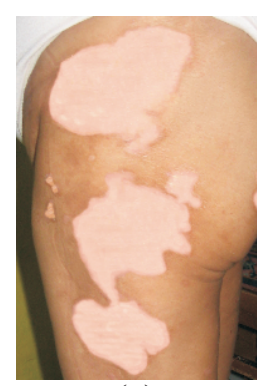

(c)

Gambar 1 (a) Foto Sebelum Terapi Kombinasi Salep Kalsipotriol 0,005\% dan Klobetasol Propionat 0,05\%

(b) Foto Satu Minggu Setelah Terapi Kombinasi Salep Kalsipotriol 0,005\% dan Klobetasol Propionat $0,05 \%$

(c) Foto Dua Minggu Setelah Terapi Kombinasi Salep Kalsipotriol 0,005\% dan Klobetasol Propionat 0,05\%

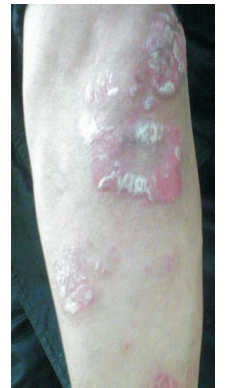

(a)

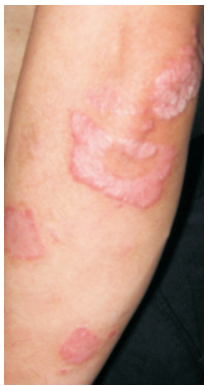

(b)

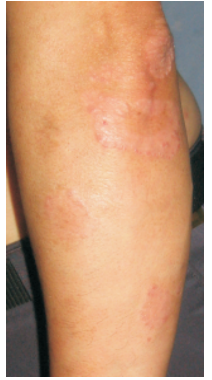

(c)

Gambar 2 (a) Foto Sebelum Terapi Salep Klobetasol Propionat 0,05\%

(b) Foto Satu Minggu Setelah Terapi Salep Klobetasol Propionat 0,05\%

(c) Foto Dua Minggu Setelah Terapi Salep Klobetasol Propionat 0,05\%

rata sebelum pengobatan 10,35; simpangan baku 4,15; median 9,5 dan rentang 4,2-21,2. Setelah pengobatan satu minggu skor PASI rata-rata turun menjadi 4,99 (51,3\%), simpangan baku 2,91; median 4,5; dan rentang $0,6-6,6$. Secara statistik penurunan ini sangat bermakna $(\mathrm{Zw}=4,107$; $\mathrm{p}<0,001)$. Dua minggu setelah pengobatan, turun menjadi $1,53(89,1 \%)$; simpangan baku 1,60 ; median 1,2 dan rentang $0-6,6$. Skor PASI pada kelompok II, sebelum serta 1 dan 2 minggu setelah pengobatan menunjukkan perbedaan bermakna $(Z w=4,107 ; p<0,001 ; Z w=4,107 ; p<0,001)$.

Pada Tabel 1 terlihat perbedaan rata-rata skor PASI sebelum dan 1 minggu setelah pengobatan menunjukkan perbedaan tidak bermakna pada kedua kelompok $(p>0,05)$, tetapi perbedaan rata- rata skor PASI setelah dua minggu pengobatan menunjukkan perbedaan yang bermakna $(\mathrm{p}=0,001)$.

Tabel 2 menunjukkan persentase penurunan skor PASI satu minggu setelah pengobatan pada kedua kelompok tidak berbeda bermakna $(p>0,05)$, tetapi persentase penurunan skor PASI dua minggu setelah pengobatan menunjukkan perbedaan yang sangat bermakna $(\mathrm{p}<0,001)$.

\section{Pembahasan}

Metode PASI digunakan untuk mengukur berat 
ringannya psoriasis dan mengevaluasi perbaikan lesi. Metode ini digunakan berdasarkan penilaian pengukuran tiga gejala klinis lesi psoriasis yang khas yaitu eritema, indurasi, dan deskuamasi. Bagian atau area tubuh yang diperiksa meliputi kepala, tubuh, dan ekstremitas. Metode ini telah digunakan secara luas oleh para klinisi di seluruh dunia. ${ }^{4}$

Pada penelitian ini, perbedaan rata-rata skor PASI sebelum dan 1 minggu setelah pengobatan pada kedua kelompok tidak menunjukkan perbedaan bermakna $(\mathrm{p}>0,05)$, tetapi perbedaan rata-rata skor PASI 2 minggu setelah pengobatan terdapat perbedaan yang bermakna $(p=0,001)$. Persentase penurunan skor PASI satu minggu setelah pengobatan pada kedua kelompok tidak terdapat perbedaan yang bermakna $(p>0,05)$, tetapi 2 minggu setelah pengobatan terdapat perbedaan yang sangat bermakna $(\mathrm{p}<0,001)$.

Penelitian Papp et $a l^{5}$ terdapat penurunan PASI sebelum sampai akhir pengobatan sebesar $73,2 \%$ pada penderita psoriasis vulgaris yang diberi terapi kombinasi salep kalsipotriol 0,005\% dan betametason dipropionat $0,05 \%$, sedangkan penderita yang mendapat monoterapi salep betametason dipropionat $0,05 \%$ terdapat penurunan sebesar $63,1 \%(p<0,001)$. Persentase penurunan PASI selama satu minggu adalah $48,1 \%$ pada kelompok kombinasi dan $41,4 \%$ pada kelompok monoterapi, perbedaannya secara statistik sangat bermakna $(p<0,001)$.

Pada penelitian Lebhowl et $a l^{6}$ selama 14 hari, keparahan penyakit setelah mendapatkan terapi kombinasi salep kalsipotriol $0,005 \%$ dan halobetasol $0,05 \%$ berkurang secara bermakna dibanding monoterapi salep halobetasol $0,05 \%$ $(p=0,017)$. Dua minggu setelah pengobatan, terdapat penurunan skor PASI sampai 0 pada $71 \%$ penderita yang mendapat terapi kombinasi dibandingkan $57 \%$ yang mendapat monoterapi salep halobetasol $0,05 \%$.

Penelitian De Jong ${ }^{7}$ mendapatkan penurunan skor PASI sebesar $65-74 \%$ pada penderita yang mendapat terapi kombinasi salep kalsipotriol $0,005 \%$ dan betametason dipropionat $0,05 \%$ selama empat minggu, sedangkan yang mendapat monoterapi salep betametason dipropionat $0,05 \%$ penurunannya 57,2-63,1\%. Ekspresi keratin 10 dan keratin 67 dapat digunakan untuk menilai efek pengobatan. Keratin 10 merupakan keratin yang berperan dalam proses diferensiasi epidermis, pada psoriasis terjadi gangguan diferensiasi yang ditandai dengan menurunnya ekspresi keratin 10 . Keratin 67 merupakan keratin yang berperan pada proses proliferasi epidermis, pada psoriasis terjadi gangguan proliferasi yang ditandai dengan meningkatnya ekspresi keratin 67. Diferensiasi sel yang dihitung dengan ekspresi keratin 10, secara bermakna lebih baik $(\mathrm{p}<0,05)$ setelah terapi kombinasi (51,6\%), dibandingkan monoterapi $(48,2 \%)$. Proliferasi sel yang dihitung dengan ekspresi Ki-67 menurun dari 14,1 sampai dengan $8,5 \%$ pada terapi kombinasi dan 11,8 sampai $6,8 \%$ pada monoterapi. Penurunan Ki-67 pada terapi kombinasi ini secara bermakna lebih rendah dibandingkan monoterapi $(\mathrm{p}<0,01)$. Penurunan persentase skor PASI setelah terapi kombinasi sebesar 68,6-73,8\% dibandingkan monoterapi sebesar $22,7-21 \%$, hal ini terjadi karena terdapat peningkatan keratin 10 dan penurunan Ki-67 yang lebih baik dan secara statistik bermakna pada terapi kombinasi dibandingkan monoterapi.

Pada penelitian Vissers et $a l^{8}$ menunjukkan penurunan persentase rata-rata $71 \%$ pada terapi kombinasi salep kalsipotriol $0,005 \%$ dan betametason dipropionat $0,05 \%$ serta $66 \%$ pada monoterapi salep betametason dipropionat $0,05 \%$. Terdapat penurunan jumlah sel dengan Ki67 pada terapi kombinasi $(\mathrm{p}<0,01)$, tetapi tidak terdapat penurunan Ki-67 yang bermakna setelah monoterapi. Pada kelompok yang mendapat terapi kombinasi didapatkan peningkatan keratin 10 yang bermakna $(p<0,06)$ dan peningkatan yang sangat bermakna pada kelompok yang mendapat monoterapi $(\mathrm{p}<0,001)$. Pada terapi kombinasi terdapat penurunan sel $\mathrm{T}(\mathrm{CD} 8, \mathrm{CD} 2, \mathrm{CD} 25)$ epidermis yang sangat bermakna $(p<0,01)$, serta penurunan sel $\mathrm{T}$ (CD4, CD45RO, CD45RA) epidermis $(p<0,05)$ dan sel $\mathrm{T}(\mathrm{CD} 161)$ dermis ( $p<0,05)$ yang bermakna, sedangkan pada pemberian monoterapi tidak terdapat penurunan sel T yang bermakna.

Kortikosteroid topikal sering menimbulkan efek samping berupa atrofi, striae, teleangiektasi, makula hipopigmentasi, serta hiperpigmentasi. Untuk Mencegah efek samping dari pemakaian kortikosteroid topikal potensi sangat kuat (salep klobetasol propionat 0,05\%), sebaiknya tidak dipergunakan lebih dari dua minggu. ${ }^{10}$

Pada penelitian ini, berdasarkan pemeriksaan fisis dari 44 orang penderita tidak ditemukan adanya efek samping.

Penelitian Papp et $a l^{5}$ melaporkan adanya efek samping berupa atrofi kulit pada kulit pretibial 
setelah pengamatan selama empat minggu, yaitu dua orang setelah terapi salep betametason dipropionat $0,05 \%$ dan satu orang setelah terapi kombinasi salep kalsipotriol $0,005 \%$ dan betametason dipropionat $0,05 \%$. Pada penelitian Kragbale dan Noerrelund, ${ }^{11}$ Douglass et al, ${ }^{12}$ Kaufman et al, ${ }^{13}$ serta Lebhowl et $a l,{ }^{6}$ ditemukan efek samping yang lebih sedikit pada penderita yang mendapat terapi kombinasi.

Pada penelitian ini dengan menggunakan uji Mann-Whitney, dilakukan uji banding efikasi terapi kombinasi salep kalsipotriol $0,005 \%$ dan klobetasol propionat $0,05 \%$ dengan monoterapi salep klobetasol propionat $0,05 \%$ selama dua minggu. Persentase penurunan skor PASI antara kelompok I dan II pada minggu pertama setelah pengobatan menunjukkan $\mathrm{Z}_{\mathrm{M}-\mathrm{w}}=1,949 ; \mathrm{p}=0,051$, yang secara statistik tidak bermakna, sedangkan sesudah minggu kedua persentase penurunannya menunjukkan $\mathrm{Z}_{\mathrm{M}-\mathrm{w}}=3,651 ; \mathrm{p}<0,001$, hasil tersebut secara statistik sangat bermakna.

Terapi kombinasi salep kalsipotriol 0,005\% satu kali sehari dan salep klobetasol propionat $0,05 \%$ satu kali sehari selama dua minggu memberikan efikasi yang lebih baik dibandingkan dengan monoterapi salep klobetasol propionat $0,05 \%$ dua kali sehari selama dua minggu, yang secara statistik sangat bermakna.

Terapi kombinasi salep kalsipotriol 0,005\% satu kali sehari dan salep klobetasol propionat $0,05 \%$ satu kali sehari dapat digunakan sebagai pilihan terapi pada penderita psoriasis vulgaris, sehingga kemungkinan efek samping yang dapat terjadi akibat pemakaian salep kortikosteroid superpoten lebih kecil.

\section{Daftar Pustaka}

1. Wiryadi BE. Epidemiologic data of psoriatic patients in dr. Cipto Mangunkusumo General Hospital (tahun 2000-2001). Psoriasis CLEAR study group inaugural meeting. Singapore, 7 May, 2004.

2. Christophers E, Mrowietz U. Psoriasis. Dalam: Freedberg IM, Eisen AZ, Wolff K, Austen KF, Goldsmith LA, Katz SI, penyunting. Fitzpatrick's dermatology in general medicine. Edisi ke-6. New
York: Mc Graw Hill Publisher; 2003. hlm. 407-27.

3. Scott LJ, Dunn CJ, Goa KL. Calcipotriol ointment. A review of its use in the management of psoriasis. Am J Clin Dermatol. 2001;2:95-120.

4. Camisa C, Helm TN, Pathy AL, Sayers ME, Wilke WS. Psoriasis. Boston: Blackwell Scientific Publisher; 1994.

5. Papp KA, Geunther L, Boyden B. Early onset of action and efficacy of a combination of calcipotriene and betametason dipropionat in the treatment of psoriasis. J Am Acad Dermatol. 2003;48: 48-54.

6. Lebhowl MD, Siskin SB, Epinette W, Breneman D, Funicella T, Kalb R, et al. A multicenter trial of calcipotriene ointment and halobetasol ointment compared with either agent alone for the treatment of psoriasis. J Am Acad Dermatol. 1996;35:268-9.

7. De Jong. Calcipotriol/betamethasone dipropionate: a review of its use in the treatment of psoriasis vulgaris. Am J Clin Dermatol. 2004;5(6): 46378.

8. Vissers WPHM, Berends M, Muys L, van Erp PEJ, de Jong EMGJ, van de Kerkof PCM. The effect of the combination of calcipotriol and betamethasone dipropionate versus both monotherapies on epidermal proliferation, keratinization and T-cell subsets in chronic plaque psorisasis. Exp Dermatol. 2004;13:106-12.

9. Hughes J, Rustin M. Corticosteroids. Clin Dermatol. 1997;15:715-21.

10. Szczerkowska-Dobosz A. Human leukocyte antigen as psoriasis inheritance and susceptibility markers. Arc Immunol Ther Exp. 2005;53:42833.

11. Kragballe K, Noerrelund KL. Efficacy of oncedaily treatment regiment with calcipotriol/betamethasone dipropionate ointment and calcipotriol ointment in psoriasis vulgaris. Br J Dermatol. 2004;50:1167-73.

12. Douglas WS, Poulin Y, Decroix J, Ortone JP, Mrowietz U, Gueliver W, et al. A new calcipotriol/betamethasone formulation with rapid onset of action was superior to monotherapy with betamethasone dipropionat or calcipotriol in psoriasis vulgaris. Acta Dermatol Venereol. 2002;82:131-5.

13. Kaufman R, Bibby AJ, Bissonnete R, Cambazard F, Chu AC, Decroix J, et al. A new calcipotriol/ betamethasone dipropionate formulation (Daivobet). Is an effective once daily treatment for psoriasis vulgaris. Dermatology. 2002;205:389-93. 